\section{Research by numbers}

\section{British grant-makers unwisely conspire with the} British government to tell researchers what to do.

BRITISH basic research should be in better shape in the coming financial year than it has been for a long time. That, at least, is the simple expectation. Since the present prime minister promised in 1980 that the science budget would be "protected", the government has dutifully indexed the annual budget for inflation - but has then required that money should be spent in unproductive ways, usually getting rid of people. And while, on two or three occasions, ministers have decreed that there should be a little extra, the cause has usually been an impending crisis. But in the coming year, there will be more than $£ 100$ million extra within the research council system, which will have $£ 826$ million at its disposal (see Nature 337, 587; 1989). So will the year ahead see the beginnings of a resurgence?

Not necessarily. Money is only a necessary, not always a sufficient, guarantor of the volume and quality of research. The privations of the past decade will not quickly lose their effect, while the still-continuing reorganization of British universities and other establishments means continued distraction. Even the extra money is not quite as extra as it seems. Of the total of $£ 107$ million, only $\$ 10$ million extra will be spent on research grants to people who, fired by a bright idea not advertised in advance, apply for them successfully. Apart from the dismal $£ 14$ million for "restructuring", the euphemism for paying people off, the rest of the extra funds will be spent in ways determined in advance either by the research councils (which have taken a sudden liking to what are called interdisciplinary research centres) or by the government (whose encouragement of Antarctic research, for example, first apparent after the Falklands War, has grown marvellously since ozone depletion was first measured from the ground at the British base at Halley Bay). Too much of the extra money will go on predetermined projects.

In dirigiste contemporary Britain, such a pattern of events may not be remarkable, which is why it seemed a sign of grace last week that the British government seemed for a time unhappy that individual researchers would win such meagre benefits from its generosity. In the event, the government, as governments will, denied even a scintilla of internal disagreement - but then acknowledged that it exists by announcing a review of the research councils' policy of putting substantial sums of new money into interdisciplinary research centres.

That is a strange development. The fondness for spending research money on autonomous research centres at universities stems from the example of successful investments in the United States and from more numerous but more modest innovations by the Wolfson Foundation in Britain. But in typical British fashion, people are looking to the new research centres not merely for research, but for the solution of related industrial problems and even the training of industrial researchers in new techniques. The themes around which the centres are organized are determined by the research councils. With the first centre (in superconductivity) established only last year, nobody can yet know how successful will be their management, in which related industries are meant to have an important voice. Nothing much has been decided about their long-term future.

If Mrs Margaret Thatcher, or some other minister, has reservations about the wisdom of the past year's rash of decisions to create more of these centres, that is entirely creditable. The research councils, supposedly the custodians of academically based research, have exacerbated the recent crisis by habitually putting too much of their resources into their own activities. The new research centres, which offer grant managers the convenience of writing one large cheque rather than several small ones, could insidiously perpetuate and even aggravate this error. It is proper that the research councils should be required to defend themselves before going too far down the road. But two ironies remain. First, the new research centres appear to have been devised so as to anticipate the government's wishes, in particular by seeking to tie academic and industrial research together. And second, if the research councils' fault is that they spend too much of their money on predesignated projects, the government's fondness for earmarking research money is even more conspicuous.

\section{Supporting universities}

\section{What is the obligation of the US federal govern- ment to university research?}

FEw documents produced by the US government have generated more intense passions in the university research community than the Office of Management and Budget's Circular A-21, which spells out the principles and procedures by which universities can recover the indirect costs associated with research. For every research grant awarded to a university researcher, an extra burden falls on the university's shared facilities: the physical plant, the library, the time of administrators and all the other entities that keep an organization going. Because the federal government pays nothing towards the costs of operating universities, it is accepted that it should meet some of the extra costs arising from research. But how much?

It may be easy to detail the specific costs of researchers' salaries, supplies and equipment used in a research project, but reaching agreement on an appropriate allocation of indirect costs has become increasingly contentious. Universities believe they are being asked to shoulder too large a share of the cost of research, researchers believe their grants are being eroded by the seemingly endlessly rising fraction withheld for indirect costs and the federal government, anxious to reduce costs where possible, is zealously seeking reductions in the softer categories such as "departmental administration" or "student service".

The arguments over Circular A-21 have in some cases degenerated to bickerings in which accountants argue whether professors can legitimately be expected to keep track of their activities in 15-minute intervals. (Such a figure may be some solace to those seeking to justify costs, but can have little relationship to reality in most research settings.) Some universities are constantly grumbling that others are treated over-generously.

The American Association of Universities (AAU), having decided in February 1987 that the issue threatened to get out of hand, assembled a committee to decide how it might be made less divisive. The result, a draft report now being circulated for comment, is an attempt to clear the air and start a reasoned debate about the nature of indirect costs. Its telling premise is that the determination of indirect costs is not simply an accounting decision, but one that cuts to the heart of the federal research enterprise.

One of the AAU committee's specific suggestions is that, in the determination of indirect costs, the operation, maintenance and depreciation of equipment and facilities should be separated from components such as administrative and library services. The argument is that that will be legitimate pressure to increase the facilities component as existing facilities continue to age, and that it will make for better-tempered negotiations between university and federal accountants if the causes of increased costs are identified, not confused with, for example, administrative costs. Another proposal would set a fixed value for the administrative component of indirect costs that would apply to all universities, thus avoiding the regular and unseemly squabbles which the percentage rates provoke.

Details apart, there is a need to move away from creative accounting in determining the financial relationship between universities and the federal government, and towards a more explicit sense of partnership that acknowledges the needs of all parties to the research effort. The AAU report will at least help to raise the profile and tenor of the debate. 